\title{
XIII.
}

\section{TREVISA WORDS AND OTHERS; RANDOM NOTES.}

\author{
By L. C. Wharton.
}

[Read at a Meeting of the Philological Society on February 7, 1913.]

TnE words discussed here present no really special or peculiar points, but have an interest chiefly as they provide evidence for or against Trevisa's authorship of a certain translation into late Middle English of that well-known worls of Publius Vegetius Renatus, the De Re Militari. The words discussed are few because they were only picked from this point of view, the definitive sorting being postponed till the period arrives for assembling the material in order to do the glossary to the text, of which I have made a first rough copy and two or three collations of other manuscripts for the Early English Text Society.

Pepull.-C'This spelling occurs in 1469 in Lord Lisle's Challenge to the Battle of Nibley, according to Mr. Jeayes in his Descriptive Catalogue of the Charters and Dhuniments . . . at Berkeley Castle (p. xxviii). The $u$ might well be e, owing to the well-known confusion of the Gothic letters $e, u$, and $n$. I am glad to shelter myself behind the authority of so considerable a palæographer in this matter, because, besides the word being phonetically interesting as spelt, I think I remember having seen peepul in some manuscripts of the century. It is not in Metcalfe's edition of Jamieson's Dictionary of the Scottish Dialect. Pepull is in the Society's Dictionary for the fifteenth-sixteenth centuries, but not peepul.

Schiltron.-In Oman's Art of War, p. $45 \mathrm{n}$., and p. 45 sq., this word is spoken of as Northern dialect for 'battle' (= aoies). It is not in the Society's dictionary in this form, but under sheltron; this form is also missing in Stratmann and in Dr. Bradley's book of 1891. It occurs in all the MSS. of Vegetius $D_{e} R$..$M$. which I have seen under various forms, e.g. $\theta$ for $i$, oun at end, etc. I found in Metcalfe's "Jamieson" of 1910 the forms: Schiltrum, schyltrum, 'an host ranged in a round form.' Barbour is quoted 
for Sceoltruma. It is curious to observe the unfitness of a word so defined to express the line of battle of an army organized on what one may perhaps without rery violent anachronism call the phalan $x$ principle.

Mevedacras, the Latin termination being unimportant, occurs in Select Charter 302 at Berkeley (Jeayes, p. 100) in the reign of Henry III. The chief point is to notice the appearance of the $v$, a familiar shape elsewhere, in a document connected with Berkeley, because such a spelling of the simple word 'head' occurs in some Vegetius ASS. 'In Dufresne Du Cange (Nutt's reprint, tom. ir, 1885) the only form giren is Heret-and that is undated, being quoted from a second (!) century life of St. Etheldreda.

Newland, Abbot. This is an alternative form of Nailheart; the abbot died in 1515 and his punning coat of arms combines a nail with a heart. This seems to be a case of the confusion of wen with $y$, which is common in the Magdalen MS. of Vegetius, as well as some others; the name of Abbot Newland is linked with that of Trevisa.

Syllabic dirision. - This is a sorely disputed and very difficult question in all languages known to me, but I am here only concerned with English. I am tempted to raise the questionperhaps the end of $S$ in the Society's Dictionary will answer me-how far regular syllibic division is the result of the introduction of printing with its fixed spacing and standardized size of letter. The following cases, all from the one Vegetius MS., are now, with one exception, quite inconceivable in print, but paralleled in early pinted books often enough :-litil low-ey, $y$ tan- $3 t, b-2 t$.

Naciouns.-In the passage from which I bave quoted this (n. 3, p. 6, of the Magdalen MS.) I hare added $i$, but the $u$ is justified by a contraction mark. The addition of the $i$ may be unnecessary, as I have found numerous cases of palatalized $c$ and $s$ before ou in this particular MS. and elsewhere. I should like to know what members think about this.

FF for copital F.-A rather ambiguous case of this occurs on fol, 10 of the same MS. If ffor is really for For, then it is a rather early instance of vicious punctuation, for it is surely objectionable to malse the explanatory clause introduced by For into a main sentence. Though originating in the use of ff for capital $F$, the $f f$ families, like the fforesters, are mostly on the Welsh border, and the value of the Welsh $f(=T)$ may have 
reinforced the effects of innate conservatism and of an ignorance which I confess I shared up to the time of delivering this paper. There is, however, a clear case of $f f=F$ on fol. 29, Julius frontinus.

An interesting point is raised by a gloss incorporated (n. 17, p. 22) by the translator after the words "work of mars", viz. "that is god off bataille". The double $f$ can harily be a capital $F$, and its remoteness from the modern pronunciation is as striking as the fact that other undeniable doublings suggest a comparison of the Ormulum with this MS.

In view of the spirit in which these notes were put together, perhaps I may refer here to some inferred readings of the text from which the translation was made. Lang, the editor of the Latin text, has not got certain words translated in chap. 1 of the first book, and a passage bracketed in Lang (p. 2) is translated in the Magdalen MS.

In chap. ii eligendi, a reading of the Jatin MS. $\Pi$, is chosen, and in ehrp. iii aut, while Lang has something else. I hope by means of these and other like inlications to reconstruct parts of the Latin text sufficient to afford evidence of its date, and so settle the disputed question who was the translator. There is a long gloss from Isidore on the office of Dictator (fol. 5), which is inserted by the translator. It was a known habit of Trevisa to make such insertions, as proved by works the attribution of which to him is clearly established.

Armor.-Whis "American" spelling is introduced by a corrector or at least a correction in the Magdalen MS. Similarly, at a later point $a$ has been inserted between but and litil man and then crased.

In chap. vii (p. 23) a very curious translation occurs. The ordinary received text is: Piscatores aucupes dulciarios linteones omnesque qui aliquid tractasse videbuntur ad gynacea pertinens. The translation runs: "Fishers, Foulers, Rymours \& gestours lecchours \& holours ne sholde nozt be chosen to knyzthode, etc." This is rather surprising, and Lang gives no variant reading which should excuse such a paraphrase.

Why a pastrycook or confectioner (= dulciarius) should be called a rymour, and a linen draper or weaver or maker of linen (linteo) should be called a gestour ( $=$ reciter) is difficult to see; also why so very definite a pair of words as lecchour and holour should be chosen for the rague and widely exclusive Latin, which would 
seem almost to exclude these two classes, being meant to cut off eunuchs, barbers, bathmen, and such-like menials, who would be "held to have had something to do with the female apartments". The two words intruded mean: lecchour, an unchaste person generally, and holour, either one satisfied with low jobs or a fornicator. See Stratmann, N.E.D., and Jamieson-Metcalfe (holl, verb, No. 2, and holk).

The translation is curious elsewhere too, e.g. robur = strengthe of liftinge, in specie = in person and shape of body.

Ordenauncs . . . Troyan and Adrian.-The spelling of 0 . is the standard one in Stratmann-Bradley; the $u n$ is written just like $n n$. $Z$ is the contraction for es, making the plural. Here Troyan is as unmistakably written with an $o$ as it is meant for the Emperor Trajan, but this form occurs (like Hanus) as a Christian name in the Fugger family in South Germany, perhaps on account of their Imperialism, and so likewise for Trajan.

To kepen degree.-The interest of this is that the $n$ is added as an afterthought in the margin of the Magdalen MS., so that we are at the transitional period when the infinitive ending in $-n$ was ceasing to exist.

Ffor nys noo thing, etc.-This form, nys, had a long run according to the Society's dictionary to 1579 , although it is not in StratmannBradley nor in Jamieson-Metcalfe. It is interesting to compare with the Bohemian for 'is not', neni.

Blethelokere.-I wondered whether such a vowel change, or perhaps alternatively such a survival of a parallel form, were possible or common in this period as Stratmann quoted bli $\gamma_{e}$ for our blithe, but it appears to be from blea $\gamma_{e}=$ timid. Cf. blethely, N.E.J).

Trev Iso.-Trev is the same thing as A.S. tin, i.e. farmstead, or practically estate. I mistakenly gave $I s a$ in my paper as upper, higher, when it is really lower. Although the farm stands high on a little eminence of its own and seems thus to justify the sense upper, the rising ground after this fall rises again to a greater height. I am tempted, nevertheless, to repeat the example of Overland Farm, Deron, which is obviously an analogous form, land being for town or farm. I want to connect this with a symbol or rebus in the manuscripts, the best form of which is a flag flying backward: 
Hargubush $=$ arquebus. This spelling is in the N.E.D., but occurs on the title of a book of 1574, G. Baker, Composition ... of . . Oleum magistrale, which is stated to be good for hargubush shot.

Vlach.-This word seems sometimes to be used for shepherd. Its equivalent in Hungarian, oláh, means 'Wallach', as it does in Roumanian, three other words being used for shepherd and herdsman. Yet, I believe, it is generally understood that olah also means shepherd, as all the shepherds of Pindus are Vlachs of one sort or another. 'l'hat it once meant gypsy as well is clear from the history of $\beta \lambda a x$ os, tin, and of the suburb of Constantinople, Blachernae, Roumanian purism has substituted pastorŭ for another word and done the same for herdsman.

The word $I^{\prime} l a c h$ is not given as current Roumanian in Damé, nor Koutzo-Vlach. Valahia is the right Roumanian name for what is better known as Muntenia, the mountainous part of Roumania. Here I want to call attention to the cruel neglect of the remotest of the Romance languages, Roumanian, called Wallachian in Diez-Donkin, whose own 'purists' are doing their best to ruin its unique vocabulary and syntax and revolutionize its phonetics. There will soon be a large etymological dictionary available by Sextil Puscariu, who has succeeded to the task of B. Petriceicu Haşdeu.

Because of my desire to hint at certain parallels with Portuguese, the furthest removed from Roumanian geographically of all the liomance group, I selected as an instance the words lemn lignum, semn signum. French drops $g$ before $m, n, r, d$, but retains it as "final", according to Brachet, in digne, long, étang, poing. Diez docs not give these as being covered by rule, but he does give a long account under stancare of the derivations of stagnum, where Donkin has some misprints. He gives a form stunge as = Italian stance. It does not seem satisfactory any more than the next under stanga ( = pole, bar), where he quotes Wall. sleange, and compares steange and tongs. $e a$ here $=\dot{e}$, phonetically $\mathrm{B}$, and $g$ becomes $g^{\prime}$ (i.e. $d z$ ) before $i$ and $e$, as in Italian. As all the other languages (our own included with Tongs) keep a nasalized an (phonetically $\tilde{a}$ ), I cannot see how Wallachian can get so different a form. I confess the difficulty of Roumanian phonetics prevents me at present from carrying this further, as I have never had the luck to hear the language spoken, but I must say that I gather that the $m n$ in lemn and so on is much more like the Polish $n$ and 
French gn than one would suppose, and thus shows a legitimate filiation and parallelism.

To recur to Brachet, surely the $g n$ in digne is only a script form for what the Spaniard represents by $\hat{n}$, and the Serbian by $H$ or $n j$, the Pole by $n$, with national differences, while $n g$ is nasal $n$, a quite different thing. (Phonetically $\gamma v, \bar{a}$.)

\section{A DDENDUM.}

A. Philippide's Specialistul Romin of 1907 is a book of special interest, which deserves notice. See also the present writer's contributions on neglected languages.

-gne certainly dues approximate somewhat to $n g$ in some dialects of French, but never in Standard French nor in that of Paris, where no distinction is audible between point and poing. Yet Brachet is hardly likely to have taken a wrong example. Poing is from pugn and etang from stagn-, while digne is from dign-, but it is obvious the two former have undergone a change to which the last has not been exposed; the only possible conclusion seems to be a slip on the part of Mr. G. W. Kitchin, the translator. 